\title{
Filipino Gurus' Perspectives on Philippine Teacher Protection Act and Their Reflections on Student Discipline and Its Present- Day Implementation
}

\author{
Aljon Delmo Galang \\ Philippine Normal University - Manila \\ 104, Taft Ave, Ermita, Manila, 1000 Metro Manila, Filipina \\ E-mail: galang.ad@pnu.edu.ph
}

\begin{tabular}{l} 
Article Info \\
\hline Received September 2020 \\
Accepted Oktober 2020 \\
Published Oktober 2020
\end{tabular}

Keywords:

Teacher Protection Act, Child Protection Policy, Student Discipline, Classroom Management.

\begin{abstract}
When Child Protection Policy (CPP) has been implemented, many teachers strive to maintain discipline and execute the curriculum through instruction. In the worst circumstances, lawsuits related to student discipline and classroom management have been filed against teachers. With this, the Philippine Congress created the bill Teacher Protection Act (TPA) primarily authored by Antonio L. Tinio, France L. Castro, and Ramon H. Durano VI. This act protects the teachers from students of bad behavior, abusing the legal empowerment from CPP. This shift leads to the conduct of this study. This phenomenological study aims to give insights about the bill (the phenomenon) and to gauge how the teacher participants perceive it (the perception). An interview is conducted among five (5) tenured teacher participants. They are asked to assess the house bill content and its future implications to provide insights to the teachers, other stakeholders, and the lawmakers. The investigation identifies that: (a) CPP is a hindrance to student discipline; (b) TPA must be immediately implemented; (c) the act is perceived to be a protection, but must be improved; (d) there are no clear guidelines to implement the act so far; (e) legal assistance in cases related to student discipline and classroom management is one of the best features of the act; (f) equality between students and teachers are perceived to be significant; (g) financial constraint is a consideration to be made to successfully implement the act; and (h) though the participants may single out some points to re-consider, they are still positive towards the act and what it can do for the welfare of the teachers.
\end{abstract}

C2020 Jurusan Ilmu Pendidikan, FKIP Universitas Lampung 


\section{INTRODUCTION}

In the advent of the Department of Education Order No. 40, s. 2012, also known as the Department of Education Child Protection Policy (R.A. 7610), last May 14, 2012, and its implementation in June 2012, the abuse towards children in school has been addressed. Elahe ( as cited by Ancho, 2019) emphasized that the Department of Education provides support to the school heads, teachers, and students to enhance their competence in the teaching and learning process. However, in the case of the discipline, it is apparent that the aforementioned department order clearly favors the welfare of the students from physical, verbal, and sexual violence that may be brought by their schoolmates and even from their teachers and other school staffs (Philippine Department of Education, 2012). From thence, the expected safe haven for students creates turmoil in correcting students' misbehaviors in schools. Discipline in the academe has become a dilemma and in worst cases, it is equated to child abuse. This results in the twist of circumstances against the teachers. Aside from the problems brought by workloads, and class observations, teachers are now bullied.

In a June 2019 report, a teacher was attacked verbally, threatened to be shot with stone, and hit with a knife. The incident takes place because the teacher confronted the student for not wearing proper uniform (GMA Public Affairs, video file, 26 June 2019). In addition, in 2018, it was also reported that two teachers in Leyte and Cavite, in just two months, committed suicide and according to their colleagues, they were complaining about their about their non-teaching related tasks, workloads and observations (Mateo, 2018). This alarms especially Sen. Juan Edgardo M. Angara.

To address the serious problem, in a press release of the Philippine Senate posted last September 4, 2018, Angara called not only for the passage of House Bill No. 135, increasing the salary of teachers, but most especially for the passage of Teacher Protection Act of 2018 (TPA 2018) Bill, also known as Senate Bill No. 1870, due to the reported incidents of the abovementioned news on teachers committing suicide (Senate of the Philippines, 2018).

Two (2) years before Angara's TPA 2018, ACT Teachers Party-List Representatives Antonio L. Tinio, the principal author, and Francisca L. Castro introduced a counterpart version of the bill in the Lower House, Teacher 
Protection Act of 2016 (TPA 2016), or also known as House Bill No. 58. The bill has been on trial since then. Tinio argued that disciplining students of today is hard and the absence of a support mechanism makes it even harder; thus, he introduced the bill.

"Instilling discipline to some 60 to 70 pupils in a class without guidelines for student discipline and mechanisms for classroom management would sometimes lead to teachers being accused of violating $R A 7610$ or the Child Protection Policy. With the passage of the Teacher Protection Act into law, there would be an institutionalization of measures governing student discipline and mechanisms for classroom management to ease the burden of public school teachers and school personnel and to establish support for their protection (Manila Bulletin, 2019)."

Due to the loud clamor, the bill is fortunately approved. On December 10, 2018, in 17th Congress, Third Regular Session, it was recommended to be approved, as signed by Ramon H. Durano IV, the Chairman of the Committee on Basic Education and Culture (CBEC). Amendments are made to the bill substituting it with the approved House Bill No. 9065 or Teacher Protection Act (TPA) (House of Representatives, 2018). On June 9th, 2019, in the 18th Congress, First Regular Session, in a House of Representatives press release, it has been announced that this bill has been unanimously approved by the 183 members of the House of Representatives (House of Representatives, 17th Congress, 2019).

Furthermore, to address the issue at hand, versions of the bill have not only been made in the House of Representatives, but also in Senate. Both houses proactively find solutions. Undeniably, House Bill No. 58 and Senate Bill No. 1870 are almost verbatim. The only difference lies in the further revisions made by CBEC in House Bill No. 9065. In addition, House Bill No. 1884 authored by Sen. Grace Poe has also been made to address the same issue (House of Representatives, 17th Congress, 2019). A lot of versions are in the mainstream, but all of them are made to solve the issue. This is a positive response to Castro's previous clamoring call. In an interview, she encouraged the senators to pass the bill's counterpart version in the Upper House for its swift law enactment (Philippine Department of Education, 2012). Consequently, the 
Philippine Legislature is resolute to address this issue that extends to the present-day classroom.

Moreover, in the classroom, it is undeniable that class management has been significant in the whole process of teaching and learning and one of its essential parts is discipline. In school, teachers have non-academic parental roles in which they serve as 'rods of love and learning (discipline)' (Galang, 2020). Discipline is intertwined with instruction since its absence may lead the class into chaos resulting to poor academic performance or even academic failure.

In Krashen's Affective Filter Hypothesis, he pointed out that if anxiety is high, learning is low and vice versa. Vis-à-vis classroom management, it can be assumed that there must be a welcoming ambiance in which students can enjoy learning (Lin, 2008). However, problems may arise when students get out of hand due to over-complacency resulting in misbehaviors. Krashen did not point out the possible result of the absence of optimal discipline-related anxiety.

Disciplining students nowadays is arduous and controversial. As mentioned earlier, due to the intervention of Child Protection Policy or also known as R.A. 7610, teachers are often restrained from executing appropriate disciplinary measures to students and accused of Child Abuse to some extent. Moreover, out of the Freudian tripartite personality, an analogy can be made. Among the students, the policy serves as their 'id' and the discipline provided by the teachers serves as their 'super-ego'. Since the super-ego is weakened due to the policy, students' id appears to be powerful and getting out of hand. Thus, it becomes a problem (Journal Psyche, 2018).

In line with this matter, the House of Representatives files House Bill No. 9065 or also known as Teacher Protection Act. This bill aims to provide protection to teachers in the course of discipline implementation. However, as the Lower and Upper Houses review the bill, teachers must also proactively participate in its evaluation since they are equipped with the experience in the field. They can provide insights to chisel the bill to reach its optimal implementation. Thus, this study is conducted. This paper provides teachers' insights that the lawmakers may use to come up with provisions suited to the development of the bill. The study aims (a) to provide insights about House Bill No. 9065 or also known as Teacher Protection Act (the phenomenon); and (b) to 
gauge the perception of the teacher participants towards today's student discipline and the act, leading to material that lawmakers may refer to in the law-making process (the perception).

\section{METHODOLOGY}

The study used a qualitative research method, particularly Phenomenological Approach. Fraenkell \& Wallen (2009) defined qualitative research method as a study involving the processes of comparing between alternative methods of teaching (as in experimental research); examining research among variables (as in correlational relationships); comparing groups of individuals in terms of existing differences on certain variables (as in causalcomparative research); or interviewing different groups of educational professionals, such as teachers, administrators, and counselors (as in survey research).

Furthermore, they also defined Phenomenological Approach as the investigation of various reactions to, or perceptions of, a particular phenomenon. Phenomenologists assume that there is some commonality to how human beings perceive and interpret similar experiences; they seek to identify, understand, and describe these commonalities. This commonality of perception is referred to as the essence-the essential characteristic(s)—of the experience. It is the essential structure of a phenomenon that researchers want to identify and describe. They do so by studying multiple perceptions of the phenomenon as experienced by different people, and by then trying to determine what is common to these perceptions and reactions.

Purposive sampling is used in this study because there are specific target participants. There are five (5) teacher participants in this study. They all teach in a Philippine public school, for three (3) to four (4) years. This project used interviewing as a way of collecting data. The researcher asked the participants to read the Bill and state their opinion and evaluation of the said bill. Thus, the interview is hermeneutic and evaluative by nature. Interviewing is an important way for a researcher to check the accuracy of-to verify or refute-the impressions he or she has gained through observation. It is described as the most important data collection technique a qualitative researcher possesses. The purpose of interviewing people is to find out what is on their minds-what they 
think or how they feel about something. Eventually, the interviews are transcribed to look for codes.

To analyze the responses of the participants, content analysis is used. Right after transcribing the interview conducted, codes are identified. They are arranged based on the emerging themes within the content of the transcriptions. Finally, out of these, a conclusion is made.

\section{RESULTS AND DISCUSSION}

This section explores the findings that emerged from the empirical investigation executed among the teacher participants. The following are the themes analyzed and derived from the interviews conducted among the participants. There are seven (7) themes in this study, extrapolating the present-day student discipline, its implementation in the Philippine classrooms, and the teachers' perception towards TPA.

\section{Today's Student Discipline Challenges Due to Child Protection Policy}

It is undeniable that discipline plays a significant role in classroom management for it is the key to an orderly class, leading to continuous and sound learning. However, today's breed of students has a different mindset as manifested in their behaviors. Parents and students feel empowered over the teachers and other school authorities and this is because of the legal empowerment given by the law which is the Child Protection Policy (DepEd Order No. 40, s. 2012 or R.A. 7610 ).

"It is hard to be a teacher and implement discipline among students nowadays because you do not want to get complaints from their parents (P4)."-Excerpt 1

"In positive discipline, we want to correct the students without getting them humiliated. You do not want to violate Child Protection Policy. Our intention is to simply teach them proper discipline (P5)." - Excerpt 2

Discipline nowadays is really arduous and controversial to implement. Many things have already changed among the way students behave nowadays. Students are now different.

"Students today have changed a lot. They are not the same as before. In the past, when teachers glanced at them, they would stop unlike today. When you talk to students today, they ignore you. That is why discipline today is a big challenge for teachers. With Child Protection Policy favoring the students, this is intensified (P2)." - Excerpt 3 
Generous amount of patience among the students is required to hone the behavior of the students especially in the public school. This is an additional clear burden to the teachers who are also considered as academic promoters and discipline implementers.

"Serving students in the public school system is really a big task with a capital "B" and a capital " $T$ ". You really need your patience, your dedication, plus the passion. Handling picked students from different walks of life is really a very big challenge nowadays (P3)." - Excerpt 4

Thus, indeed, RA 7610 is one of the contributors to why discipline nowadays is really hard to implement among students aside from the fact that they are from different upbringings. It requires patience and sensitivity in its execution making it really hard for the teachers to achieve their academic and valuesoriented goals. In worst cases, disciplinary actions are taken as child abuse.

\section{Cases of Disciplinary Action Taken as Child Abuse}

The teacher participants observed that disciplinary actions may be taken as child abuse in our current situations. These actions may lead to legal suits against the teachers who simply teach students the discipline needed to develop holistically their well-being.

"Even a drop of misinterpretation in disciplining the students may lead to an accusation that you violate the students' right (P2)." - Excerpt 6

On a TV show, a 55-year old teacher is accused of child abuse for telling her student to get outside of the room. The parent and the guardian insisted that the act led to the traumatization of the child. However, in the teacher's defense, she said that she did it to discipline the student. This is the reason that one of the participants said,

“This may be brought up due to Ms. Limjuco's case aired on Raffy Tulfo's Show. She allegedly abused physically a child. There must be confidentiality in dealing with the case. She received mockery from the public due to many allegations against her. The case was not given proper resolution (P1)." - Excerpt 7

As observed by the participants, to students, teachers' way of disciplining students can be taken as a big deal. The students tend to antagonize teachers when they verbally discipline them since they are aware of R.A. 7610. Students' respect for their teachers is affected. 
"When teachers get mad at them, it becomes a big deal. The teachers just want them to learn. Students' discipline today deteriorates as well as their respect for teachers (P5)." - Excerpt 8

Due to these circumstances, it is high time to implement the legal basis that will serve as protection for discipline implementers such as the teachers. The initiative of the Congress to come up with such bill is indeed of great help.

\section{Teacher Protection Act as a Shield for Discipline Implementers}

As perceived by the teachers, the Act is indeed a tool that will help them in the implementation of discipline in the academe. Since the Child Protection Policy is legalized in the earlier years, there must also be a tool that will cater the emerging needs of teachers to hone the whole aspects of the students especially in character formation.

"As a teacher, I understand that students must be protected, but the ones guiding them must also have equal protection (P2)." - Excerpt 9

As emphasized by one of the participants in an interview, TPA is perceived to be a shield that will protect the teachers in the campus discipline implementation.

"Okay, after reading this material prepared by the good gentleman in the lower house I was able to sense that the paper may be of good help on the teachers most specially in the public school system. We really need this paper to become a shield, as a protection among public servants (P3)." Excerpt 10

As stated in TPA, Section 11, the Department shall provide legal assistance to the teachers in case charges related to student discipline and class management shall be filed against them. This is seen positively by the teachers who are afraid to move forward in disciplining students.

"In terms of legal assistance, it is good. At least, teachers will be given support in terms of legal assistance. He lor she] will not find it hard to deal with legalities (P1)."-Excerpt 11

The act serves as a protection to teachers; however, it cannot be ignored that it has parts to improve on, based on the perception of the teacher participants.

\section{The Ambiguity of Teacher Protection Act Guidelines}

The participants find the guidelines or procedures of implementing discipline unclear since they are not specified in the bill. They look for its more comprehensible version. In fact, one of them said, 
"Next, it shall promote and improve the working conditions of public school teachers and other school personnel. However, I do not see any specific guidelines to follow (P1)." - Excerpt 12

The participants look for the clear guidelines because they want to know the demarcation line or the limits of student discipline. They are after the clear procedure on how to give appropriate disciplinary action. A participant said,

"There is no clear limit for teachers in disciplining the students to correct their wrong behavior (P2)." - Excerpt 13

They also emphasize that it must be stated clearly to give confidence to those who execute discipline in the classroom. It is important that the teachers know what they are going to do especially in this facet of classroom management that is essential in holistic learning. One of them stated,

"I cannot find any backbone from this house bill. How I wish they can be more specific as for the mechanics on how it will be implemented down to the classroom and a more specific refill of the laws of 7610. It sounds very "suntok sa buwan (punch to the moon)" as they say it. Maybe a more improved version of this material will really give a good melody, good music to all the teachers in the public school system for them to be more confident before they enter the classroom, and every time they deal with these challenges encountered every time, they are performing and delivering their role and task as teachers and second parent (P3)." - Excerpt 14

In summary, the teacher participants look for clearer guidelines in student discipline implementation to know its demarcation line and to gain confidence in teaching the students. Nonetheless, since the act is still a bill, the implementing rules and regulations (IRR) are not yet published, and during the interview, the teachers are not yet informed about the law-making process. Nevertheless, they are educated about this process after the interview.

In the implementation process, sometimes it is inevitable for some teachers to be involved in cases related to student discipline and classroom management and there is no other way but to handle it properly.

\section{Proper Handling of Teachers' Child Abuse Cases}

As stated in Excerpt 7, one of the participants emphasized that case confidentiality is very important to handle properly teachers' cases related to student discipline and classroom management. In addition, one of the participants also pointed out that giving legal assistance is a generous act so that the teachers will not resort to resignation if they shall be involved in such cases. 
"What I like the most about this Teacher Protection Act is with regards to the legal assistance that will be provided to the teachers which is mentioned in Section 11. That is protection for teachers and school personnel in charges related to the student discipline and classroom management. Yes, we have the PAO or the Public Attorney's Office but then it would really be better if it's the Department of Education itself that would extend the legal help or legal assistance to teachers because if we're going to think about it, there are a lot of issues that teachers face but they do not have the power to protect themselves, considering that it is a knowledge for most people that most teachers are plunged in tons of loans. So what money will they spend to find legal assistance when they are sued? I wouldn't be surprised if their last option is resignation. But it is a good thing in this Teacher Protection Act that DepEd shall provide legal assistance to teachers facing criminal and administrative charges (P2)." - Excerpt 15

Legal assistance to be given to teachers is a sign of equality since everyone, whether a student or a teacher, must be protected under the rule of law and this is also pointed out by the participants.

\section{Equal Human Rights between Students and Teachers}

Human right is the gift of equality in the land governed by the law and it does not choose age or social status. One of the participants said,

"Even though without this act, I myself tell the children that we do have rights as teachers because we are also humans. We are also citizens with rights, not only as teachers but also as persons."- Excerpt 16

In Excerpt 9, as one of the participants stated, the students need protection and so are the teachers. This only shows that equal rights must be given to both parties. Upon considering this matter and the optimum implementation of the Act, the notion cited by a participant that DepEd takes the side of the students most of the time will be removed from the minds of the citizens especially of the teachers.

"Through Teacher Protection Act, we are given protection in times that we felt abused by the students. Department of Education primarily focuses on Child Protection Policy that students use to abuse their rights (P5)."-Excerpt 17

Maintaining equal rights in the eyes of the law is what these participants seek. Though the clamor for the implementation of the act is apparent, it is indeed not an easy task to do. Challenges may occur in its execution.

\section{Challenges of Teacher Protection Act Presumed Implementation}

The participants presumed that there may be challenges along the way as the act governs the system such as what is being pointed out. There may be a 
problem in the allocation of funds to hire guidance counselors or in hiring qualified ones to help assist in the implementation.

"However, I would like to point out in Section 9 of this act about support personnel. It says here that the Department of Budget and Management shall also ensure that there is a sufficient number of items for guidance counselors who will serve as support personnel to teachers and school administrators in matters of student discipline. Honestly speaking, it is hard to achieve the goal of having sufficient number of items for guidance counselors just to satisfy this Teacher Protection Act. Because in reality, when the K-12 program is implemented there are no guidance counselors given to Senior High School. It means the number of students has increased, but the number of guidance counselors does not. It says here that there should be a ratio of one guidance counselor for every 200 students in public elementary and high schools, but that does not happen. In fact, they just appoint guidance teachers who are not licensed guidance counselors. The intention is good, but there must be sufficient number of guidance counselors (P2)."- Excerpt 18

One of the participants sees a financial constraint in the implementation of the act. This time, the lack of funds for training and related instructional materials is seen. Nonetheless, these are very significant in the success of its execution.

"Teaching through discipline is not given importance. So with regards to the establishment of this act, I think it is hard to implement this due to lack of funds based on Section No. 7. It is stated that the training of teachers and school personnel on the guidelines all employees of the division shall annually receive instructions related to the specific content of the guidance. So we need a lot of funds in order for us to have related training materials and in order for us to deliver this kind of act (P5)." - Excerpt 19

Financial constraint is definitely a consideration to be made to successfully implement the act. Though the participants may single some points to reconsider, they are also positive towards it and what it can do for the welfare of the teachers.

\section{The Teacher Participants' Perception and Hope towards the Bill}

The participants see the good intention of the Teacher Protection Act to provide protection to the teachers and legal assistance in times of legal suits. They may see lacking essential parts, but they are still positive towards it. As one of them expressed,

"Finally, I could say the intention ng Teacher Protection Act is very good. I just hope that this will be implemented as soon as possible for the benefit of teachers (P2)." - Excerpt 20

As stated in Excerpt 10, one of the participants perceives this act as something positive and helpful to the teachers in the field as they go on the 
process of instruction. All of the participants hope for the best. In the interviews, they expressed their hopes for this bill. They see it as a tremendous help and protection for teachers. As the participants said,

"Hopefully, this act shall be implemented at last for the protection of the teachers (P2)." - Excerpt 21

"They have given us hope. May this bill provide us with complete protection. Thank you (P3)." - Excerpt 22

There may be some points to improve on, but the teacher participants are indeed hopeful and positive that all the teachers will benefit and be protected with the help of the Teacher Protection Act.

\section{CONCLUSION}

After analyzing the data gathered, the following conclusions are derived:

On Teacher Protection Act. TPA is made to address the needs of the teachers in the process of implementing discipline in the academe. It sets the limits of disciplinary interventions that can be made by the teachers. However, the measures are still to be set by the Department of Education upon the approval of the Lower and Upper Houses. Moreover, there are other salient features included in the act. Legal support shall also be extended to the teachers in case of lawsuits related to student discipline and classroom management. In addition, training with the aid of instructional materials shall be held and additional guidance counselors shall be hired.

On Teachers' Perception. To the teachers, RA 7610 is one of the contributors to why discipline nowadays is really hard to implement among students aside from the fact that they are from different upbringings. They believe that discipline requires patience and sensitivity in its execution making it really hard for the teachers to achieve their academic and values-oriented goals. In worst cases, as they observe, disciplinary actions are taken as child abuse. Due to these circumstances, they point out that it is high time to implement a legal foundation that will serve as protection for discipline implementers such as the teachers. As they see it, the initiative of Congress to come up with such a bill is of great help. To them, the act serves as a protection to teachers; however, it cannot be ignored that it has parts to improve on based on the perception of the teacher participants. 
As perceived, financial constraint is definitely a consideration to be made to successfully implement the act. Though the participants may single some points to re-consider, they are also positive towards the act and what it can do for the welfare of the teachers. The participants hope for the best. There may be some points to improve on, but the teacher participants are indeed hopeful and positive that all the teachers will benefit and be protected with the help of TPA. Ultimately, this legal protection will contribute a lot in the practice of the teaching profession.

\section{REFERENCES}

Ancho, I. (2019). Preferred future of Filipino leadership. Research and Development Journal Suan Sunandha Rajabhat University, Vol. 11, No.1: 1-12. Retrieved from https://so05.tcithaijo.org/index.php/irdssru/article/view/145239

Fraenkell, J. \& Wallen, N. (2009). How to design and evaluate research in education. New York, USA: McGraw-Hill Higher Education.

Galang, A. (2020). Non-academic constructs of Thai and Filipino $21^{\text {st }}$ century teachers in the movie "Teacher's Diary". OKARA Journal, Vol. 4, N0.2: 190-208. DOI: http://dx.doi.org/10.19105/ojbs.v14i2.3529

GMA Public Affairs. (2019, June 26). Stand for truth: Teachers protection act, isinusulong! [Video file]. $\quad$ Retrieved from https://www.youtube.com/watch?v=F5N-10mJK_c

House of Representatives. (2018). Teacher protection act [Fact sheet]. Retrieved from http://www.congress.gov.ph/legisdocs/first 17/CR01223.pdf

House of Representatives. (2019, June 9). House okays bill institutionalizing support and protection mechanisms for public school teachers [Press release].

Lin, G.C.H. (2008). Pedagogies proving Krashen's theory of affective filter. Chinese Culture University, Chine: Hwa Kang Journal of English Language \& Literature, No. 14 (July 2008), pp. 113-131.

Mateo, J. (August 30, 2018). DepEd probes teacher suicides. The Philippine Star. Retrieved from https://www.philstar.com/other-sections/educationand-home 
Philippine Department of Education (2012). DepEd child protection policy (DepEd Publication No.1190). Retrieved from https://www.deped.gov.ph/wp-content/uploads/2012/05/DO_s2012_40.pdf

Senate of the Philippines. (2018, September 4). Angara calls for passage of teacher protection bill amid reported suicide of teachers [Press release]. Retrieved from https://www.senate.gov.ph/press_release/2018/0904_angara1.asp

Teacher Protection Act of 2016, House Bill No.58, 17th Congress. (2016). Retrieved from http://www.congress.gov.ph/press/details.php?pressid=11542

Teacher Protection Act, House Bill No. 1884, 17th Congress. (2018).

The Freudian theory of personality. (2018). Journal Psyche. Retrieved from http://journalpsyche.org/the-freudian-theory-of-personality/ 